\title{
ROUTINELY AVAILABLE BIOMARKERS AS LONG-TERM PREDICTORS OF DEVELOPING SYSTOLIC DYSFUNCTION IN COMPLETELY REVASCULARIZED PATIENTS WITH ACUTE ST ELEVATION MYOCARDIAL INFARCTION
}

\author{
Ivan Zeljković ${ }^{1}$ Šime Manola ${ }^{1}$, Vjekoslav Radeljić ${ }^{1}$, Diana Delić Brkljačić ${ }^{1}$, \\ Alen Babacanli ${ }^{2}$ and Nikola Pavlović ${ }^{1}$ \\ ${ }^{1}$ Department of Cardiology, Sestre milosrdnice University Hospital Centre, Zagreb, Croatia; \\ ${ }^{2}$ Department of Emergency Medicine, Sestre milosrdnice University Hospital Centre, Zagreb, Croatia
}

SUMMARY - The aim of this study was to assess the efficacy of high-sensitivity C-reactive protein (hsCRP), cardiac troponin $\mathrm{T}(\mathrm{cTnT})$ and creatine kinase $(\mathrm{CK})$ as long-term predictors of reduced systolic function in patients with acute ST-segment elevation myocardial infarction (STEMI) undergoing primary percutaneous coronary intervention (PCI) with complete revascularization. This prospective study evaluated consecutive patients with acute STEMI who had normal left ventricular ejection fraction ( $\mathrm{LVEF} \geq 50 \%$ ) at admission with single-vessel disease and underwent complete revascularization. Blood samples were collected from admission to day 7. The primary endpoint was reduction of LVEF $<50 \%$ after 12 months. The study included 47 patients, median age $59 \pm 10$ years, $74.5 \%$ of them men. Patients who developed systolic dysfunction (LVEF $<50 \%)$ had significantly higher mean values of cTnT after 24 hours (5.11 vs. $2.82 \mu \mathrm{g} / \mathrm{L}, \mathrm{p}=0.010$ ) and peak values of CK (3375.5 vs. $1865 \mathrm{U} / \mathrm{L}, \mathrm{p}=0.008)$. There was no significant relation between hsCRP and development of reduced LVEF ( $\mathrm{p}=0.541$ ). In conclusion, $\mathrm{cTnT}$ and CK could serve as long-term predictors of reduced left ventricular systolic function $(<50 \%)$ in acute STEMI patients with normal systolic function at admission, single-vessel coronary disease and complete revascularization during primary PCI.

Key words: Myocardial infarction; C-reactive protein; Creatine kinase; Troponin T; Percutaneous coronary intervention; Prognosis

\section{Introduction}

Primary percutaneous coronary intervention (PCI) is a favorable treatment for patients with acute myocardial infarction with ST-segment elevation (STE$\mathrm{MI}$ ) and is in most instances effective in assessing revascularization ${ }^{1,2}$. Although completely revascularized patients as a heterogeneous population had better

Correspondence to: Ivan Zeljkovic, MD, Department of Cardiology, Sestre milosrdnice University Hospital Centre, Vinogradska c. 29, HR-10000 Zagreb, Croatia

E-mail: ivanzeljkov@gmail.com

Received July 20, 2017, accepted November 15, 2017 clinical results than non-revascularized patients, revascularization need not necessarily lead to reperfusion ${ }^{3,4}$. Therefore, patients should be stratified on the basis of presenting either low or high risk of developing systolic dysfunction in order to select high-risk patients who could then undergo a stricter clinical follow-up. Clinical risk scores and angiographic lesion classification have already been used to identify high-risk patients with acute STEMI. Several of them (e.g., CADILLAC or GRACE) have provided important prognostic information and have already been using biomarkers as a constituent part ${ }^{5,6}$. Nowadays, several cardiac biomarkers have been used to a great extent by 
clinicians because of their predictive value for clinical outcomes following cardiovascular events ${ }^{7-9}$. Measuring non-cardiac and cardiac biomarkers may prove to be very useful for risk prediction and therefore can facilitate the selection of high-risk patients. Higher levels of B-type natriuretic peptide (BNP), cardiac troponin $\mathrm{T}$ or I (cTnT or $\mathrm{cTnI})$, and high-sensitivity C-reactive protein (hsCRP) are proportionally related to higher ratios of major cardiovascular events after acute coronary syndrome ${ }^{7-10}$. Due to this fact, the mentioned biomarkers presenting different parts of complex STEMI pathophysiological mechanisms have been used for assessing STEMI risk and prognosis. New biomarkers are the focus of many studies since they can provide additional risk information; however, they are not widely available, especially in developing countries ${ }^{11}$. Therefore, our aim was to assess the predictive value of routinely available biomarkers, separately or combined, on the basis of which clinical risk could be predicted in a low-risk group of completely revascularized, single-vessel acute STEMI patients. The above mentioned biomarkers were used because they are routinely available and they present different parts of the pathophysiological cascade of the coronary disease, i.e. $\mathrm{cTnT}$ and creatine kinase (CK) as markers of myocardial necrosis and size of infarction affected myocardium, and hsCRP as a marker of acute inflammatory phase, produced in response to inflammation stimuli that contribute significantly to atherosclerosis, accelerating both atherosclerosis and plaque rupture and consequential thrombotic complications ${ }^{7-10}$.

The aim of the study was to investigate the ability of cTnT, CK and hsCRP in predicting the long-term risk of developing systolic dysfunction after 12 months in the population hospitalized with acute STEMI with previously normal left ventricular ejection fraction (LVEF) and with single-vessel coronary disease undergoing complete and successful revascularization. It is noteworthy to disclose that this study included the same study population as a previously published study by the same authors, in which the predictive role of proBNP was evaluated ${ }^{9}$, the usage of which is too expensive in everyday clinical work and cannot be used routinely, especially in developing countries.

\section{Materials and Methods}

This was a prospective, single-centre study including acute STEMI patients hospitalized in the Sestre mi-

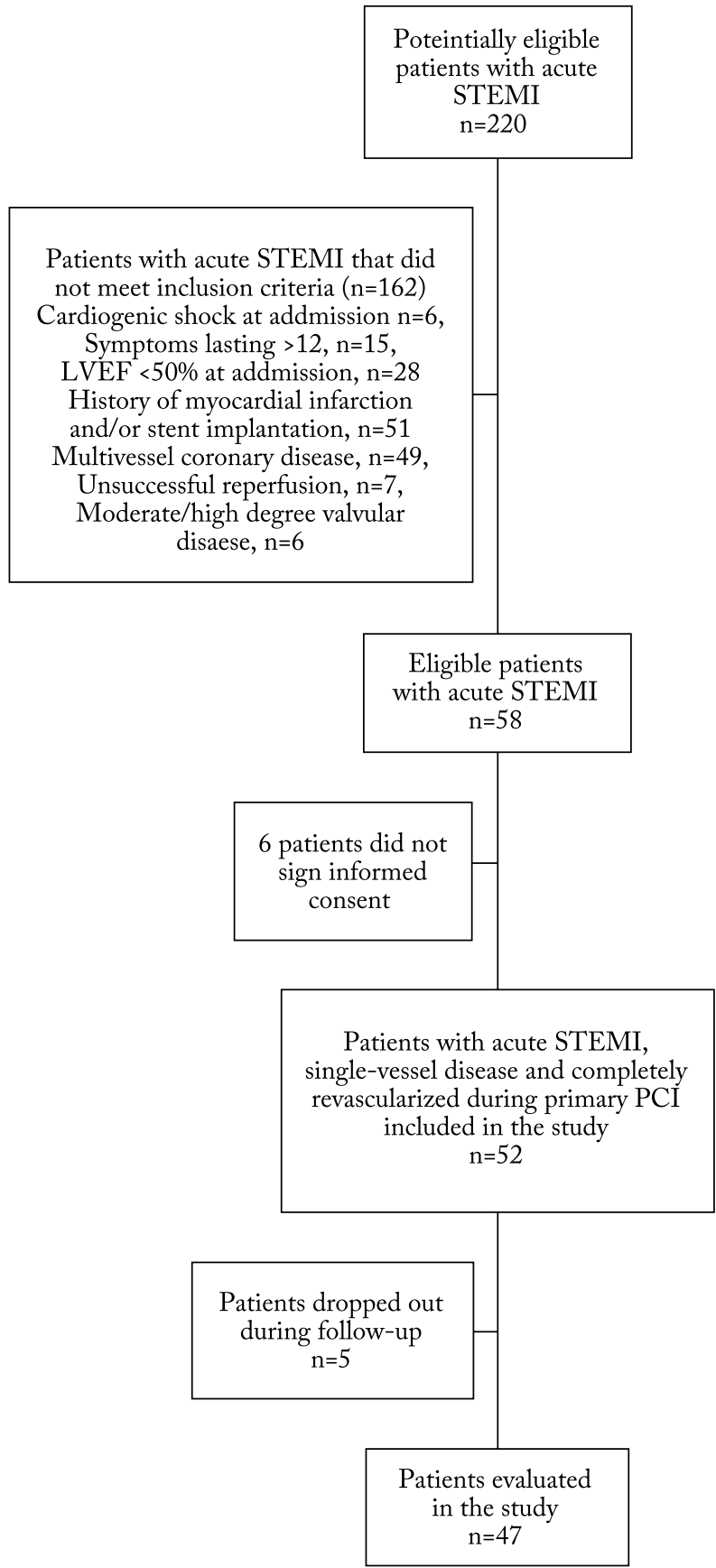

Fig. 1. Study flowchart.

STEMI = ST-segment elevation myocardial infarction; LVEF = left ventricular ejection fraction; $\mathrm{PCI}=$ percutaneous coronary intervention

losrdnice University Hospital Centre, Zagreb, Croatia. We prospectively studied patients that underwent primary PCI within 12 hours of the onset of symptoms, had normal LVEF ( $\geq 50 \%$ ) at admission, had only sin- 
gle-vessel coronary disease, and underwent complete and successful revascularization (thrombolysis in myocardial infarction (TIMI) III flow and myocardial blush grade (MBG) III) during primary PCI. Moreover, patients who had cardiogenic shock, symptoms lasting for $>12$ hours, significant double- or triplevessel coronary disease including left main coronary artery, unsuccessful reperfusion, history of myocardial infarction, and moderate or high degree valvular disease were excluded from the study (Fig. 1).

Patients were admitted through emergency department, where they underwent assessment of the onset and duration of pain, comorbidities and risk factors, and complete physical status. A 12-lead electrocardiogram (ECG) was obtained in all patients and those who had acute STEMI immediately underwent primary PCI. Treatment of all patients was in line with the existing international guidelines for $\mathrm{PCIs}^{12}$. All patients signed informed consent for PCI and participation in the study before undergoing primary PCI. The study protocol complied with the Good Clinical Practice and the Declaration of Helsinki, and the Hospital Ethics Committee approved the study.

\section{Coronary angiography}

Before the procedure started, all patients received $300 \mathrm{mg}$ of acetylsalicylic acid (ASA) and $600 \mathrm{mg}$ of clopidogrel per os, as well as a total of $100 \mathrm{IU} / \mathrm{kg}$ of unfractionated heparin (3000-5000 IU iv. in bolus after arterial sheath placement and additional 3000$5000 \mathrm{IU}$ before PCI). All coronary angiographies were performed using the transfemoral approach. During coronary angiography, left ventriculogram was performed and LVEF was calculated in each patient with 2 standard projections: left anterior oblique $60^{\circ}$ and right anterior oblique $30^{\circ}$._After detecting the infarctrelated artery, stent implantation in culprit lesion was performed using standard techniques ${ }^{12}$. TIMI angiographic scale and MBG score were used to determine revascularization of the infarct-related artery ${ }^{13}$.

After having undergone primary PCI, all patients were admitted to the coronary care unit where they received routine therapy for acute STEMI according to the international guidelines ${ }^{12}$, and additional medical therapy was left to the discretion of the attending physician depending on the patient's clinical status. Echocardiography was performed using the standard protocol 3-5 days after primary PCI and LVEF was calculated using Simpson and Teicholz methods ${ }^{14,15}$. Patients were discharged 7-10 days after admission and continued to receive therapy according to the international guidelines ${ }^{12}$, as well as additional medical therapy depending on the patient's clinical status.

\section{Biochemistry and blood sampling}

Peripheral blood samples for routine laboratory tests were collected into plastic tubes (EDTA $1.5 \mathrm{mg} /$ $\mathrm{mL}$ ) and obtained on admission, after $12 \mathrm{~h}$, on day 1 and on day 7. Lipid profile was measured once, 24 hours after admission. CK levels were monitored until normalization using spectrophotometry (Olympus 680, Beckman Coulter Inc., California, USA) and the laboratory set the reference value between 0 and 153 $\mathrm{U} / \mathrm{L}$ at $37^{\circ} \mathrm{C}$. The concentration of cTnT was determined by using electrochemiluminescence assay ( $\mathrm{Co}^{-}$ bas e 411, Roche Diagnostics, Sussex, UK) and positive cTnT on admission was defined as any value higher than $0.1 \mu \mathrm{g} / \mathrm{L}$. The hsCRP value was measured using an immunoturbidimetric assay (Olympus 680, Beckman Coulter Inc., California, USA) and dichotomized at a the cut-off limit of $\geq 11 \mathrm{mg} / \mathrm{L}$, as assessed in previous studies ${ }^{16-18}$. Moreover, patients were divided into quartiles on the basis of their hsCRP and cTnT levels, which is a standard model to assess the impact of biomarkers in the population.

\section{Follow-up}

During the 12-month follow-up, all patients were evaluated at 6 and 12 months. Clinical examination, laboratory tests including complete blood count, CK, hsCRP, cTnT, NT-proBNP and creatinine, as well as ECG stress test were carried out during check-up. Also, echocardiography was done at 6 and 12 months after discharge and without knowing the biomarker results.

\section{Endpoints}

The primary endpoint was systolic dysfunction defined as reduced LVEF to less than 50\% with or without heart failure clinical signs and symptoms, at 12 months after acute myocardial infarction.

\section{Statistical analysis}

Quantitative data were expressed as median values and corresponding ranges. Differences in quantitative 
Table 1. Demographic, clinical and angiographic characteristics of two study groups: group $A$ (LVEF <50\%) and group $B(L V E F \geq 50 \%)$

\begin{tabular}{|c|c|c|c|}
\hline & $\begin{array}{l}\text { Group A } \\
\text { LVEF <50\% } \\
\mathrm{n}=21\end{array}$ & $\begin{array}{l}\text { Group B } \\
\mathrm{LVEF} \geq 50 \% \\
n=26\end{array}$ & $\begin{array}{l}\text { Statistical } \\
\text { significance } \\
\text { p value }\end{array}$ \\
\hline Age (years) & $59(37-77)$ & $56(47-74)$ & 0.471 \\
\hline Body mass index $\left(\mathrm{kg} / \mathrm{m}^{2}\right)$ & $27.7(20.2-31.2)$ & $29.6(23.9-39.8)$ & 0.031 \\
\hline \multicolumn{4}{|l|}{ Sex } \\
\hline $\begin{array}{l}\text { male } \\
\text { female }\end{array}$ & $\begin{array}{l}13(61.9 \%) \\
8(38.1 \%)\end{array}$ & $\begin{array}{l}23(88.5 \%) \\
3(11.5 \%)\end{array}$ & 0.058 \\
\hline Hypertension & $11(52.4 \%)$ & $17(65.4 \%)$ & 0.681 \\
\hline Diabetes mellitus & $9(42.9 \%)$ & $12(46.2 \%)$ & 0.825 \\
\hline Hyperlipoproteinemia & $4(19.0 \%)$ & $16(61.5 \%)$ & 0.012 \\
\hline Smoking & $9(42.9 \%)$ & $16(61.5 \%)$ & 0.413 \\
\hline Positive family history & $11(52.4 \%)$ & $16(61.5 \%)$ & 0.885 \\
\hline \multicolumn{4}{|l|}{ Culprit lesion } \\
\hline LAD & $11(52.4 \%)$ & $6(23.1 \%)$ & \multirow{3}{*}{0.048} \\
\hline $\mathrm{ACx}$ & $3(14.3 \%)$ & $3(11.5 \%)$ & \\
\hline $\mathrm{RCA}$ & $6(28.6 \%)$ & $17(65.4 \%)$ & \\
\hline $\mathrm{hsCRP} \geq 11 \mathrm{mg} / \mathrm{L}$ at admission $(\mathrm{mg} / \mathrm{L})$ & $3(14.3 \%)$ & $0(0.0 \%)$ & - \\
\hline hsCRP $\geq 11 \mathrm{mg} / \mathrm{L}$ after $24 \mathrm{~h}(\mathrm{mg} / \mathrm{L})$ & $17(80.9 \%)$ & $19(73.1 \%)$ & 0.541 \\
\hline Peak levels of CK (U/L) & $3375.5(1254-8310)$ & $1865(325-14297)$ & 0.008 \\
\hline $\mathrm{cTnT}$ at admission $(\mu \mathrm{g} / \mathrm{L})$ & $0.065(0.01-1.35)$ & $0.052(0.01-0.65)$ & 0.575 \\
\hline cTnT after $24 \mathrm{~h}(\mu \mathrm{g} / \mathrm{L})$ & $5.11(1.08-10.12)$ & $2.825(0.4-11.62)$ & 0.010 \\
\hline
\end{tabular}

$\mathrm{LVEF}=$ left ventricular ejection fraction; $\mathrm{LAD}=$ left anterior descending coronary artery; $\mathrm{ACx}=$ circumflex coronary artery; $\mathrm{RCA}=$ right coronary artery; hsCRP = high-sensitivity $\mathrm{C}$-reactive protein; $\mathrm{CK}=$ creatine kinase; $\mathrm{cTnT}=$ cardiac troponin $\mathrm{T}$

variables between the groups were tested by MannWhitney U-test (non-parametric test for independent samples). Qualitative data were expressed in contingency tables as absolute values and percentages. The relation between qualitative variables and patient groups was tested by $\chi^{2}$-test with Yates corrections. Association between biomarkers and clinical outcome ( $\mathrm{LVEF}<50 \%$ or $\geq 50 \%$ ) was evaluated by use of logistic regression. The distribution of particular variables was tested using Kolmogorov-Smirnov test and logarithmic transformations were used as appropriate. The multivariable model of logistic regression was created and its receiver operating characteristic (ROC) curve was constructed to assess the accuracy of biomarkers and multimarker score to predict clinical outcome (LVEF $<50 \%)$. The values of $\mathrm{p}<0.05$ were considered statistically significant. STATISTICA software, version 6.0 for Windows (Dell Software, StatSoft Inc., Tulsa, USA) was used on statistical analysis.

\section{Results}

Out of a total of 220 consecutive acute STEMI patients admitted to the hospital during the one-year study period, 58 patients met the inclusion/exclusion criteria (Fig. 1). Additionally, six patients refused to participate in the study, whereas five patients dropped out during the follow-up period (all underwent follow-up at another institution) (Fig. 1). Consequently, the study population included 47 patients, and $74.5 \%$ of them were male, median age $59 \pm 10$ years and mean body mass index (BMI) $28.9 \pm 4.3 \mathrm{~kg} / \mathrm{m}^{2}$. The duration of chest pain at admission was $137.7 \pm 94.5$ minutes. At admission, all 47 patients had normal systolic function (LVEF $\geq 55 \%$ ) with single-vessel coronary disease and underwent primary PCI with stent implantation and complete revascularization. During the 12-month follow-up, 21 patients developed echocardiographic signs of reduced LVEF $<50 \%$. The study patients were di- 
Table 2. Predictive values for prediction of reduced left ventricular ejection fraction $<50 \%$ after 12-month follow-up

\begin{tabular}{|l|l|l|l|l|}
\hline & \multirow{2}{*}{$\begin{array}{l}\text { Odds } \\
\text { ratio }\end{array}$} & \multicolumn{2}{|l|}{ 95\% confidence interval } & \multirow{2}{*}{ p value } \\
\cline { 3 - 4 } & 0.780 & Minimum & Maximum & \\
\hline Body mass index & 0.227 & 0.06 & 0.97 & 0.028 \\
\hline RCA & 4.074 & 1.11 & 0.82 & 0.025 \\
\hline LAD & 3.168 & 1.16 & 15.01 & 0.035 \\
\hline CK $(\log )$ & 3.342 & 1.17 & 8.64 & 0.025 \\
\hline cTnT after 24 h $(\log )$ & 6.272 & 1.35 & 9.52 & 0.025 \\
\hline cTnT Q4 after 24 h & & 29.07 & 0.002 \\
\hline
\end{tabular}

$\mathrm{RCA}=$ right coronary artery; $\mathrm{LAD}=$ left anterior descending coronary artery; $\mathrm{CK}=$ creatine kinase; $\mathrm{cTnT}=$ cardiac troponin $\mathrm{T}$

vided into two groups: group A, $\mathrm{LVEF}<50 \%$ and group $\mathrm{B}, \mathrm{LVEF} \geq 50 \%$.

Baseline demographic, clinical and angiographic characteristics of the two study groups are shown in Table 1. Group A patients (LVEF <50\%) in comparison with group B patients had lower BMI (27.7 vs. 29.6; $\mathrm{p}=0.031$ ) and consequently lower incidence of hyperlipoproteinemia ( $20 \%$ vs. $61.5 \%$; $\mathrm{p}=0.012)$. Other demographic and clinical characteristics did not differ significantly between the study groups.

\section{Biomarkers and follow-up outcome}

The levels of cTnT at admission did not significantly differ between the study groups $(\mathrm{p}=0.575)$, as opposed to the levels of cTnT after 24 hours, which were higher in group A (5.11 vs. $2.82 \mu \mathrm{g} / \mathrm{L} ; \mathrm{p}=0.010)$. When we divided patients into quartiles according to cTnT values after 24 hours, odds ratio for the primary end-point in patients with cTnT after 24 hours in Q4 was 6.27 (95\% CI, 1.35-29.06; $\mathrm{p}=0.020)$ as compared with Q1-Q3 patients. Also, the peak values of CK were significantly higher in group A (3375.5 vs. 1865 $\mathrm{U} / \mathrm{L} ; \mathrm{p}=0.008$ ). There was no significant relation between hsCRP levels at admission or after 24 hours and development of heart failure during the 12-month follow-up, either when the values were dichotomized at a cut-off limit of $\geq 11 \mathrm{mg} / \mathrm{L}$ (17 patients in group A vs. 19 patients in group $\mathrm{B} ; \mathrm{p}=0.541$ ) or when they were split into quartiles $(\mathrm{p}=0.848)$. Predictive values for reduced LVEF after 12 months are presented in Table 2.

Additionally, considering infarct-related artery, left anterior descending (LAD) artery was more common in group A ( $\mathrm{LVEF}<50 \%)$, whereas right coronary ar-



Fig. 2. Receiver operating characteristic (ROC) curve analysis for multimarker score as a predictor of left ventricular systolic dysfunction after 12 months.

Receiver operating characteristic (ROC) curve analysis for multimarker score, consisting of cardiac troponin $\mathrm{T}$ after $24 \mathrm{~h}$, peak levels of creatine kinase and left anterior descending coronary artery as an infarct-related artery, as a predictor of left ventricular systolic dysfunction after 12 months. Sensitivity $65.0 \%$ (95\% confidence interval $11.1-87.9 \%)$; specificity $84.6 \%$ (95\% confidence interval $21.2-$ $94.5 \%)$; area under the ROC curve $=0.825$.

tery (RCA) was more common in group $B(p=0.048)$ (Table 1); when using logistic regression, we found that patients with LAD as an infarct-related artery were 4 times more likely to develop LVEF $<50 \%$ (OR 4.074; 95\% CI 1.11-15.01; $\mathrm{p}=0.035$ ) (Table 2). Furthermore, we created a biomarker score that included peak values of $\mathrm{CK}$ and levels of cTnT after 24 hours 
and $\mathrm{ROC}$ curve analysis did not show prognostic value of this score for predicting reduced systolic function 12 months after STEMI: sensitivity 70.0\% (95\% CI $0-100 \%)$ and specificity $80.7 \%$ (95\% CI 0-100\%) with the area under the ROC curve 0.817 . However, when we added LAD as an infarct-related artery to this score, the predictive value was slightly better with $65 \%$ sensitivity (95\% CI 11.1-87.9\%), 84.6\% specificity (95\% CI 21.2-94.5\%), and area under the ROC curve $=0.825$ (Fig. 2).

\section{Discussion}

The study represented a prospective, single-centre experience in a specific group of patients with acute STE$\mathrm{MI}$ and only one affected coronary artery that underwent primary $\mathrm{PCI}$ within $12 \mathrm{~h}$ of the onset of symptoms with successful and complete revascularization. This group of patients is considered as low-risk and has the best long-term prognosis, as well as a low incidence of unwanted outcomes. Therefore, they are often not in the primary focus of clinicians, which should not be the case since among this population with a great potential of complete recovery, there are patients which are at a higher risk of developing systolic dysfunction.

According to our findings, which are in agreement with most previous similar studies ${ }^{19-21}$, the levels of cTnT after 24 hours, both mean values and when divided into quartiles, as well as the peak levels of CK were higher in the group of patients that developed reduced systolic function with LVEF $<50 \%$ after oneyear follow-up, taking into account that patients with cTnT in Q4 were six times more likely to develop it. Regarding hsCRP, for which the results of previous studies are ambiguous ${ }^{17,18,20}$, we found that the values $\geq 11 \mathrm{mg} / \mathrm{L}$ did not differ between the study groups, either at admission or after 24 hours, and that this biomarker had no predictive value in this specific group of patients with acute STEMI. Considering the above mentioned, cTnT and CK could be used as long-term predictors of developing reduced systolic function ( $\mathrm{LVEF}<50 \%$ ) in this very homogeneous group of $\mathrm{pa}^{-}$ tients, usually considered as low-risk population. It is important because the long-term prognosis differs considerably for this population and consequently risk stratification is very important. There are a number of studies investigating the same problem and yielding very similar results, but they included more heterogeneous groups of patients $s^{6,11,16,20}$. Contrary to previous studies in which re-hospitalization, acute coronary syndrome, major adverse cardiovascular events or death (separately or combined) were taken as an endpoint $t^{7,11,16-19}$, our study took systolic dysfunction as an endpoint.

In order to obtain better risk prognosis, there is a tendency to develop multimarker scores, which are not easy to design but which could provide additional information and be better in stratifying the risk ${ }^{22}$. Moreover, several studies showed controversial results regarding multimarker scores leading to better risk stratification in comparison to clinical scores ${ }^{6,8,22,23}$, which is in correlation with our results. Non-routinely available biomarkers were also used in the studies, but they proved to be inefficient in several studies, whereas in others they provided additional information and improved risk stratification ${ }^{24}$. However, their usage is too expensive and they cannot be used routinely, especially in developing countries. Therefore, we studied only routinely available biomarkers.

In line with other studies ${ }^{25}$, we found that LAD as an infarct-related artery led to a higher incidence of left ventricular systolic dysfunction, which means that $\mathrm{pa}^{-}$ tients with complete revascularization after STEMI and with single-vessel disease affecting LAD were at a higher risk (odds ratio 4 times higher).

The results of this study should be considered in the light of certain limitations. This prospective study represented a single-centre experience in a small sample of patients; however, these patients are very specific, making a rather small group in the population of STEMI patients, and are considered as low-risk with the low incidence of unwanted outcomes. Moreover, due to the small number of patients, statistical analysis could not be performed between particular groups and data should be cautiously interpreted. Because of these limitations, our findings will have to be validated in larger clinical trials.

In conclusion, $\mathrm{cTnT}$ and $\mathrm{CK}$ could be predictors of left ventricular systolic dysfunction $(<50 \%)$ in acute STEMI patients who had normal systolic function at admission, single-vessel coronary disease, and were successfully and completely revascularized during primary PCI. Moreover, a multimarker score consisting of cTnT after 24 hours, CK and LAD has a predictive value and could also be used as a long-term predictor. These biomarkers could be used to differentiate pa- 
tients, in this specific low-risk group of STEMI patients, who are at a higher risk of developing systolic dysfunction, and therefore could be clinically followedup more often.

\section{References}

1. Keeley EC, Boura JA, Grines CL. Primary angioplasty versus intravenous thrombolytic therapy for acute myocardial infarction: a quantitative review of 23 randomised trials. Lancet. 2003;361:13-20. DOI: 10.1016/S0140-6736(03)12113-7

2. Zijlstra F, Hoorntje JC, de Boer MJ, Reiffers S, Miedema K, Ottervanger JP, et al. Long-term benefit of primary angioplasty as compared with thrombolytic therapy for acute myocardial infarction. N Engl J Med. 1999;341:1413-9. DOI: 10.1056/ NEJM199911043411901

3. Ito H, Tomooka T, Sakai N, Yu H, Higashino Y, Fujii K, et al. Lack of myocardial reperfusion immediately after successful thrombolysis: a predictor of poor recovery of left ventricular function in anterior myocardial infarction. Circulation. 1992; 85:1699-705. DOI: 10.1161/01.CIR.85.5.1699

4. Ito H, Maruyama A, Iwakura K, Takiuchi S, Masuyama T, Hori $\mathrm{M}$, et al. Clinical implication of the "no reflow" phenomenon: a predictor of complication and left ventricular remodeling in reperfused anterior wall myocardial infarction. Circulation. 1996;93:223-8. DOI: 10.1161/01.CIR.93.2.223

5. Ellis SG, Guetta V, Miller D, Whitlow PL, Topol EJ. Relation between lesion characteristics and risk with percutaneous intervention in the stent and glycoprotein IIb/IIIa era: an analysis of results from 10907 lesions and proposal for new classification scheme. Circulation. 1999;100:1971-6.

DOI: 10.1161/01.CIR.100.19.1971

6. Lev EI, Kornowski R, Vaknin-Assa H, Porter A, Teplitsky I, Ben-Dor I, et al. Comparison of the predictive value of four different risk scores for outcomes of patients with ST-elevation acute myocardial infarction undergoing primary percutaneous coronary intervention. Am J Cardiol. 2008;102:6-11. DOI: 10.1016/j.amjcard.2008.02.088

7. Wang TJ, Gona P, Larson MG, Tofler GH, Levy D, NewtonCheh C, et al. Multiple biomarkers for the prediction of first major cardiovascular events and death. N Engl J Med. 2006; 355:2631-9. DOI: 10.1056/NEJMoa055373

8. Foussas SG, Zairis MN, Lyras AG, Patsourakos NG, Tsirimpis VG, Katsaros $\mathrm{K}$, et al. Early prognostic usefulness of C-reactive protein added to the thrombolysis in myocardial infarction risk score in acute coronary syndromes. Am J Cardiol. 2005; 96:533-7. DOI: 10.1016/j.amjcard.2005.04.015

9. Manola S, Pavlović N, Radeljić V, Delić Brkljačić D, Pintarić $\mathrm{H}$, Štambuk K, et al. B-type natriuretic peptide as predictor of heart failure in patients with acute ST elevation myocardial infarction, single-vessel disease, and complete revascularization: follow-up study. Croat Med J. 2009;50:449-54. DOI: 10.3325/ cmj.2009.50.449
10. Hoffmann R, Suliman H, Haager P, Christott P, Lepper W, Radke PW, et al. Association of C-reactive protein and myocardial perfusion in patients with ST-elevation acute myocardial infarction. Atherosclerosis. 2006;186:177-83. DOI: 10.1016/j.atherosclerosis.2005.07.011

11. Brügger-Andersen $T$, Aarsetøy $H$, Grundt $H$, Staines $H$, Nilsen DW. The long-term prognostic value of multiple biomarkers following a myocardial infarction. Thromb Res. 2008; 123:60-6. DOI: 10.1016/j.thromres.2008.01.012

12. Steg PG,James SK, Atar D, Badano LP, Blömstrom-Lundqvist $\mathrm{C}$, Borger MA, et al. Task Force on the management of ST-segment elevation acute myocardial infarction of the European Society of Cardiology (ESC). 2012. ESC Guidelines for the management of acute myocardial infarction in patients presenting with ST-segment elevation. Eur Heart J. 2012;33: 2569-619. DOI: 10.1093/eurheartj/ehs215

13. van ' $t$ Hof AW, Liem A, Suryapranata H, Hoorntje JC, de Boer MJ, Zijlstra F. Angiographic assessment of myocardial reperfusion in patients treated with primary angioplasty for acute myocardial infarction: myocardial blush grade. Zwolle Myocardial Infarction Study Group. Circulation. 1998;97:2302-6. DOI: 10.1161/01.CIR.97.23.2302

14. Chapman CB, Baker O, Reynolds J, Bonte FJ. Use of biplane cinefluorography for measurement of ventricular volume. Circulation. 1958;18:1105-17. DOI: 10.1161/01.CIR.18.6.1105

15. Teichholz LE, Kreulen T, Herman MV, Gorlin R. Problems in echocardiographic volume determinations: echocardiographicangiographic correlations in the presence or absence of asynergy. Am J Cardiol. 1976;37:7-11. DOI: 10.1016/00029149(76)90491-4

16. Brügger-Andersen T, Pönitz V, Staines H, Pritchard D, Grundt $\mathrm{H}$, Nilsen DW. B-type natriuretic peptide is a long-term predictor of all-cause mortality, whereas high-sensitive $\mathrm{C}$-reactive protein predicts recurrent short-term troponin $\mathrm{T}$ positive cardiac events in chest pain patients: a prognostic study. BMC Cardiovasc Disord. 2008;8:34. DOI: 10.1186/1471-2261-8-34

17. Chew DP, Bhatt DL, Robbins MA, Penn MS, Schneider JP, Lauer MS, et al. Incremental prognostic value of elevated baseline $\mathrm{C}$-reactive protein among established markers of risk in percutaneous coronary intervention. Circulation. 2001;104: 992-7. DOI: $10.1161 / \mathrm{hc} 3401.095074$

18. Ndrepepa G, Braun S, Iijima R, Keta D, Byrne RA, Schulz S, et al. Total leucocyte count, but not $\mathrm{C}$-reactive protein, predicts 1-year mortality in patients with acute coronary syndromes treated with percutaneous coronary intervention. Clin Sci (Lond). 2009;116:651-8. DOI: 10.1042/CS20080298

19. Roubille F, Samri A, Cornillet L, Sportouch-Dukhan C, Davy JM, Raczka F, et al. Routinely-feasible multiple biomarkers score to predict prognosis after revascularized STEMI. Eur J Intern Med. 2010;21:131-6. DOI: 10.1016/j.ejim.2009.11.011

20. Chan $\mathrm{D}, \mathrm{Ng}$ LL. Biomarkers in acute myocardial infarction. BMC Med. 2010;8:34. DOI: 10.1186/1741-7015-8-34

21. Kim D, Choi DH, Kim BB, Choi SW, Park KH, Song H. Prediction of infarct transmurality from $\mathrm{C}$-reactive protein level and mean platelet volume in patients with ST-elevation 
myocardial infarction: comparison of the predictive values of cardiac enzymes. J Clin Lab Anal. 2016;30:930-40. DOI: 10.1002/jcla.21959

22. Morrow DA, Braunwald E. Future of biomarkers in acute coronary syndromes: moving toward a multimarker strategy. Circulation. 2003;108:250-2.

DOI: 10.1161/01.CIR.0000078080.37974.D2

23. Wang TJ, Gona P, Larson MG, Tofler GH, Levy D, NewtonCheh C, et al. Multiple biomarkers for the prediction of first major cardiovascular events and death. N Engl J Med. 2006; 355:2631-9. DOI: 10.1056/NEJMoa055373
24. Di Stefano R, Di Bello V, Barsotti MC, Grigoratos C, Armani $\mathrm{C}$, Dell'Omodarme $\mathrm{M}$, et al. Inflammatory markers and cardiac function in acute coronary syndrome: difference in ST-segment elevation myocardial infarction (STEMI) and in non-STEMI models. Biomed Pharmacother. 2009;63:773-80.

DOI: 10.1016/j.biopha.2009.06.004

25. Chen ZW, Yu ZQ, Yang HB, Chen YH, Qian JY, Shu XH, et al. Rapid predictors for the occurrence of reduced left ventricular ejection fraction between $\mathrm{LAD}$ and non-LAD related ST-elevation myocardial infarction. BMC Cardiovasc Disord. 2016;16:3. DOI: 10.1186/s12872-015-0178-y

Sažetak

\section{RUTINSKI DOSTUPNI BIOMARKERI KAO PREDIKTORI RAZVOJA SISTOLIČKE DISFUNKCIJE TIJEKOM DUGOROČNOG PRAĆENJA BOLESNIKA S POTPUNO REVASKULARIZIRANIM AKUTNIM INFARKTOM MIOKARDA SA ST ELEVACIJOM}

\section{Zeljković, Š. Manola, V. Radeljić, D. Delić Brkljačić, A. Babacanli i N. Pavlović}

Cilj istraživanja bio je utvrditi učinkovitost visokoosjetljivog C-reaktivnog proteina (hsCRP), kardijalnog troponina T $(\mathrm{cTnT})$ i kreatin kinaze (CK) kao dugoročnih prediktora razvoja sistoličke disfunkcije u bolesnika sa STEMI-infarktom kojima je učinjena potpuna revaskularizacija tijekom primarne perkutane koronarne intervencije (PCI). Provedena je prospektivna studija kojom su evaluirani uzastopni bolesnici s akutnim STEMI-infarktom koji su imali urednu sistoličku funkciju kod prijma uz jednožilnu koronarnu bolest i koji su potpuno revaskularizirani tijekom primarne PCI. Uzorci krvi su prikupljani od prijma do 7. dana hospitalizacije. Primarni ishod bio je razvoj sistoličke disfunkcije lijevog ventrikla (LVEF $<50 \%)$ nakon godinu dana. $U$ istraživanje je bilo uključeno 47 bolesnika s medijanom dobi $59 \pm 10$ godina i $74,5 \%$ su bili muškarci. Bolesnici koji su razvili sistoličku disfunkciju (LVEF <50\%) su imali značajno više vrijednosti cTnT nakon 24 sata $(5,11$ prema $2,82 \mu \mathrm{g} / \mathrm{L}, \mathrm{p}=0,010)$ i više maksimalne vrijednosti CK $(3375,5$ prema $1865 \mathrm{U} / \mathrm{L}, \mathrm{p}=0,008)$. Nije utvrđena povezanost između hsCRP-a i razvoja sistoličke disfunkcije $(\mathrm{p}=0,541)$. Zaključak je da cTnT i CK mogu poslužiti kao dugoročni prediktori snižene sistoličke funkcije lijevog ventrikla $(<50 \%)$ u bolesnika s akutnim STEMI-infarktom koji su imali urednu sistoličku funkciju kod prijma uz jednožilnu koronarnu bolest i koji su potpuno revaskularizirani tijekom primarne PCI.

Ključne riječi: Infarkt miokarda; C-reaktivni protein; Kreatin kinaza; Troponin T; Perkutana koronarna intervencija; Prognoza 